\begin{tabular}{|l|l|l||}
\hline \multicolumn{2}{|c|}{ PublisherInfo } \\
\hline \hline PublisherName & $:$ & BioMed Central \\
\hline \hline PublisherLocation & $:$ & London \\
\hline \hline PublisherImprintName & $:$ & BioMed Central \\
\hline \hline
\end{tabular}

\title{
Survival of the not-so-fit
}

\begin{tabular}{|l|l|l||}
\hline \multicolumn{2}{|c|}{ ArticleInfo } \\
\hline \hline ArticleID & $:$ & 4827 \\
\hline \hline ArticleDOI & $:$ & $10.1186 /$ gb-spotlight-20030814-01 \\
\hline \hline ArticleCitationID & $:$ & spotlight-20030814-01 \\
\hline \hline ArticleSequenceNumber & $:$ & 179 \\
\hline \hline ArticleCategory & $:$ & Research news \\
\hline ArticleFirstPage & $:$ & 1 \\
\hline \hline ArticleLastPage & $:$ & 2 \\
\hline \hline & & RegistrationDate : 2003-8-14 \\
\hline ArticleHistory & $:$ & OnlineDate \\
\hline \hline ArticleCopyright & $:$ & BioMed Central Ltd2003-8-14 \\
\hline \hline ArticleGrants & $:$ & \\
\hline \hline ArticleContext & $:$ & 130594411 \\
\hline \hline
\end{tabular}




\section{Cathy Holding}

Email: cholding@hgmp.mrc.ac.uk

Bordetella pertussis, B. parapertussis, and B. bronchiseptica are three related pathogens that cause whooping cough and other respiratory diseases in humans and animals. One hypothesis to explain the relationship among the disease agents is that acquisition of genes leads to a gain of function that confers specificity of host and symptoms on a particular species. In the August 10 Nature Genetics, Julian Parkhill and colleagues, based at the Sanger Institute, show by sequencing and comparison of the genomes of all three pathogens that it is a loss of genes and regulatory elements that has caused relatively recent independent derivations of $B$. pertussis and B. parapertussis from B. bronchiseptica, following rearrangements and insertions by insertion sequence elements (ISEs) in their genomes (Nature Genetics 2003, DOI:10.1038/Ng1227).

Parkhill et al. demonstrated this in part by the presence of unique gene sequences in $B$. bronchiseptica, the absence of evidence of horizontal gene transfer in $B$. bronchiseptica, and the presence of ISEs on the boundaries of rearrangements. From linear genomic comparison, they discovered that while $B$. parapertussis and B. bronchiseptica show a large degree of colinearity of genome organization, an unprecedented overall genomic rearrangement has occurred in B. pertussis, with short blocks of almost perfect conservation being broken up by nearly 150 individual rearrangements, $88 \%$ of which are bounded by ISEs. The authors also showed that both $B$. pertussis and B. parapertussis exhibit substantial gene loss and inactivation through pseudogene formation and that these genes function predominantly in transport, small-molecule metabolism, regulation, and surface structures.

"Such ISE expansions have previously been seen in rarely recombining organisms whose effective population size was greatly reduced by an evolutionary bottleneck... It may be that $B$. pertussis followed [its] evolutionary path owing to the opportunities for increased transmission rate provided by the increase in size and density of the populations of its specific host, Homo sapiens," conclude the authors.

\section{References}

1. Pertussis of adults and infants

2. Nature Genetics, [http://www.nature.com/ng/]

3. The Wellcome Trust Sanger Institute, [http://www.sanger.ac.uk/]

This PDF file was created after publication. 